PERM JOURNAL OF PETROLEUM AND MINING ENGINEERING

ВЕСТНИК ПНИПУ. ГЕОЛОГИЯ. НЕФТЕТАЗОВОЕ И ГОРНОЕ ДЕЈО

ISSN 2224-9923

Volume/ Toм 18 №1, 2018

http://vestnik-pstu.ru/geo/

УДК 622.276.55:622.87

Article / Статья

(C) PNRPU / ПНИПУ, 2018

\title{
THE HYGIENIC RISK ASSESSMENT OF THE DEVELOPMENT OF OCCUPATIONAL DISEASES AMONG PERSONNEL THAT WORK IN THERMAL MINING OIL RECOVERY
}

\section{Taras V. Grunskoy, Aleksandr G. Berdnik, Maria M. Berdnik}

Ukhta state technical university (13 Pervomayskaya st., Ukhta, Komi Republic, 169300, Russian Federation)

\section{ГИГИЕНИЧЕСКАЯ ОЦЕНКА РИСКА РАЗВИТИЯ ПРОФЗАБОЛЕВАНИЙ У РАБОТНИКОВ, ЗАНЯТЫХ ТЕРМОШАХТНОЙ ДОБЫЧЕЙ НЕФТИ}

\section{Т.В. Грунской, А.Г. Бердник, М.М. Бердник}

Ухтинский государственный технический университет (169300, Россия, Республика Коми, г. Ухта, ул. Первомайская, 13)

Received / Получена: 12.07.2018. Accepted / Принята: 03.09.2018. Published / Опубликована: 28.09.2018

Key words:

thermal mining oil recovery, occupational diseases, professional risk, Yarega high-viscosity oil field, underground personnel, labor protection management system.

Ключевые слова: термошахтный способ добычи нефти, профзаболевания, профриск, Ярегское месторождение высоковязкой нефти, подземный персонал, система управления охраной труда.

\begin{abstract}
Early detection of occupational pathology is one of the areas of prevention of the diseases of workers employed in hazardous and dangerous areas of work. Medical examinations are carried out to ensure the protection of personnel health

Nevertheless, value of such examinations is decreased due to the lack of consideration of inspections results in collaboration with the labor protection service. Therefore, there is a need to use information systems for dynamic monitoring of personnel health when technological process is intensive.

Such important components as working conditions, occupational morbidity and changes in health status are not summarized in the existing hygienic assessment of professional risks in the management system. Therefore, occupational safety measures duplicate each other in the workplaces and departments of the organization, are formed without taking into account deviations in health status personnel and production risks.

Thus, it is necessary to conduct analytical studies, which include the analysis and assessment of occupational diseases, working conditions, occupational examinations. According to results of the studies an electronic database should be created. The purpose of the stage is both to analyze data on working conditions, occupational diseases, state of personnel' health and to create an algorithm to improve the system of
occupational risks management. This will allow to carry out the comprehensive assessment of the occupational risk to determine occupational diseases at earlier stages, identify the predisposition to occupational diseases and develop targeted preventive, rehabilitation measures and individual recommendations to preserve personnel' health. The results of the evaluation of the professional risk can be used to monitor the impact of working conditions on changes in the health status of workers in conditions of technical re-equipment of production.

Based on the information of Yareganeft Oil Mine Control Unit, the production health disorders (diseases of the musculoskeletal system, cardiovascular systems, musculoskeletal system, hearing impairment) of workers (drifter, timber man, operator of oil and gas production, operator of a mining machine, employees of the management staff etc.) is evaluated depending on working conditions, work experience. The number of cases of work incapacity with the establishment of reasons was estimated. Indicators of relative risk and class of working conditions depending on the profession are given.
\end{abstract}

Одним из направлений профилактики заболеваемости работников, занятых во вредных и опасных сферах труда, является раннее выявление профпатологии. Для обеспечения защиты здоровья персонала проводятся профосмотры, но их ценность снижается из-за отсутствия учета результатов осмотров во взаимодействии со службой охраны труда, поэтому существует потребность использования информационных систем для динамического наблюдения за здоровьем персонала при интенсификации технологического процесса.

В существующем алгоритме гигиенической оценки профрисков в системе управления не обобщены такие важные составляющие, как условия труда, профзаболеваемость и изменения в состоянии здоровья, следовательно, мероприятия по охране труда дублируют друг друга по рабочим местам и структурным подразделениям организации, формируются без учета отклонений в состоянии здоровья персонала и производственных рисков.

Поэтому необходимо провести аналитические исследования, которые включают в себя анализ и оценку профессиональных заболеваний, условий труда, результатов профосмотров, в итоге должна быть создана электронная база данных. Целью этого этапа является не только анализ данных об условиях труда, о профзаболеваниях и состоянии здоровья персонала, но и создание алгоритма для совершенствования системы управления профрисками. Это позволит провести комплексную оценку профриска для определения формирования профзаболеваний на более ранних этапах, выявить предрасположенность к возникновению профессиональных заболеваний и разработать направленные профилактические и реабилитационные мероприятия и индивидуальные рекомендации по сохранению здоровья персонала. Результаты оценки профриска можно использовать для мониторинга влияния условий труда на изменения в состоянии здоровья работников в условиях технического перевооружения производства.

В статье на основе использования информации по предприятию НШУ «Яреганефть» оценена производственная обусловленность нарушений в состоянии здоровья (заболевания костно-мышечной, сердечно-сосудистой систем, опорнодвигательного аппарата, нарушения слуха) работников (проходчики, крепильщики, операторы по добыче нефти и газа, машинисты горных выемочных машин, сотрудники аппарата управления и др.) в зависимости от условий труда, стажа работы. Оценено количество случаев нетрудоспособности с установлением причин. Приведены показатели относительного риска и класса условий труда в зависимости от профессии

Taras V. Grunskoy - Senior Lecturer at the Department of Industrial Safety and Environmental Protection (tel.: +007 82167745 13, e-mail: uxtacity@yandex.ru). Aleksandr G. Berdnik - PhD in Engineering, Associate Professor at the Department of Industrial Safety and Environmental Protection (tel.: +007 904 273158, e-mail: zav pbioos@ugtu.net). The contact person for correspondence.

Maria M. Berdnik - PhD in Engineering, Associate Professor, at the Department of Design and Operation of Main Gas and Oil Pipelines (tel.: +007 9048658605 , e-mail: m-berdnik@yandex.ru).

Грунской Тарас Валерьевич - старший преподаватель кафедры промышленной безопасности и охраны окружающей среды (тел.: +007 8216774513 , e-mail: uxtacity@yandex.ru). Бердник Александр Григорьеивч - кандидат технических наук, доцент кафедры промышленной безопасности и охраны окружающей среды (тел.: +007 904273158 , e-mail: aberdnik@ugtu.net). Контактное лицо для переписки.

Бердник Мария Михайловна - кандидат технических наук, доцент кафедры проектирования и эксплуатации магистральных газонефтепроводов (тел.: +007 9048658605 , e-mail: m-berdnik@yandex.ru). 


\section{Introduction}

Over the last 16 years the number of occupational diseases in thermal mining oil recovery is still large, which is true for $\mathrm{OMCU}$ Yareganeft as well. The average number of the entire enterprise Yaregneft comprises 2,526 people, 1,917 of which work in oil mines and are classified as underground personnel [1].

The large number of occupational disease indicates the insufficiency of measures taken to preserve health and reduce the impact of harmful and hazardous working conditions (HHWC). A worker is usually affected by combined influence of factors of the working environment. Thus, the large number of occupational diseases among underground workers is caused by low efficiency of the industrial safety department. High efficiency requires change in the part of the assessment of professional risks to increase.

\section{Analytical review \\ of occupational diseases of underground personnel of oil mines}

When analyzing the work experience of timbermen and drifters under the influence of harmful factors, it has been established that occupational diseases may appear already with a work experience of 5 years ( 3 people).

An analysis of the correlation between the length of work experience and the number of established occupational diseases among people working underground from 2002 to 2016, showed that the diagnosis of occupational disease is most often set in persons with experience in hazardous working conditions for more than 10 years. That is caused by the fact that duration of the impact of a complex of harmful production factors on an employee's body is important for the development of occupational pathology. There is a reliability of $\mathrm{p}<0.05$ for differences in parameters in vibration pathology, radiculopathy and hearing loss in comparison with the control group. There are no significant differences in the reflex myatonic syndrome. The number of occupational diseases, depending on work experience in hazardous working conditions is presented in Table 1 .
Table 1

The number of occupational diseases depending on the period of service in hazardous working conditions

\begin{tabular}{|l|c|c|}
\hline $\begin{array}{c}\text { Period of service } \\
\text { in hazardous } \\
\text { conditions, years }\end{array}$ & $\begin{array}{c}\text { Number of } \\
\text { employees }\end{array}$ & $\begin{array}{c}\text { Quote of all } \\
\text { occupational } \\
\text { diseases, \% }\end{array}$ \\
\hline Up to 5 & - & - \\
\hline From 5 to 9 & 22 & 19.6 \\
\hline From 10 to 15 & 63 & 47.4 \\
\hline From 16 to 20 & 37 & 33.0 \\
\hline From 21 to 30 & - & - \\
\hline
\end{tabular}

There was no ocupational disease deterimned between people of 20-29 years old while diagnosing 170 disease in the period from 2002 to 2016. That corresponds to the fact that the largest number of cases of occupational diseases is registered among workers aged 40 to 49 years. It is necessary to note the almost equal number of cases of workers in the age group from 30 to 39 years and over 50 years, which tells about occupational diseases that become young.

An analytical review of data on the disability of personnel at oil mines showed that diseases of the respiratory system $(42 \%)$ were in the structure of morbidity ( $42 \%)$, and diseases of the digestive system $(22 \%)$ and organs of the musculoskeletal system and connective issue $(19 \%)$ ranked second one. The third place is occupied by diseases of the circulatory system $(17 \%)$. The average duration of stay on the sicklist was 14.8 days for underground personnel and 14.7 days for those who work in the management apparatus.

The average number of cases of work incapacity per year is 2091 which is taken by all oil mine management with a total average number of days 30,929. The overwhelming majority of cases of incapacity for work are accounted for by underground personnel $-1,687$ cases with a total number of days of incapacity for work 25,146. Compared to 2015, the number of cases of disability in 2016 increased by 145 with a simultaneous increase in the average number of employees by 161 people. At the end of 2016, the loss of working time for sick leave amounted to $5.6 \%$, compared with 2015 , by $0.3 \%$ more, while 
for workers this figure is higher than the previous one by $0.5 \%$.

A review of the deaths between oil mines workers who were in the age of retirement or close to it revealed that the average life expectancy is 57.8 years, which is 13 years less than the average one for Russia and 11 years less than in the Komi Republic, which is among the regions with low life expectancy compared with Russia, where the average life expectancy is 2 years lower.

The major part of oil mines personnel live in urban-type settlement Yarega. The average life expectancy there was 63 years. The average life expectancy for men is only 60.6 years, which is lower than the values for the Komi Republic (69.1 years) and Russia (70.9 years). For the period from 2011 to 201517 people of the oil mines' staff died. The number of deceased employees by year was distributed as follows: in 2011 - 5 people, from 2012 to 2014 - 1 person per year, in $2015-9$. Violence was the main reason of deaths (9 people), diseases of the cardiovascular system was second (5 people), diseases of the gastrointestinal tract was the third one - (2 people). According to the analysis performed, in 67 cases of death of personnel of oil mines (full-time and retired) the main diseases that caused death were identified as follows: circulatory diseases $-44 \%$, oncology $18 \%$, diseases of the digestive organs $-8 \%$, respiratory diseases $-4 \%$, infectious diseases $2 \%$, external causes $-15 \%$, other $-9 \%$.

\section{Risk assessment of the development of occupational diseases among personnel that work in thermal mining oil recovery}

There was no diseases in the group of 20 to 29 years old workers for the period of 2002-2016 out of 170 cases of occupational diseases detected in the underground personnel of the Yarega oil mines. The risk values are obtained using the expert-statistical method of professional risk assessment. Standard deviation in the calculations 6.8. The difference with control is significant $(p<0.05)$, the sign is considered statistical; the number of occupational diseases required to ensure statistical error is $10 \%$, i.e. condition is met.

Results of the assessment of the risk of occupational disease on the basis of a statistical analysis of occupational diseases in underground personnel during thermal mining oil recovery are given in Table 2.

The risk assessment carried out does not take into account changes in the state of health of the personnel, but only the probability of obtaining occupational disease, the fact of obtaining occupational disease and work experience in hazardous working conditions are recorded. For a more accurate assessment of the level of occupational risk for the health of underground personnel, it is necessary to take into account working conditions, occupational morbidity and deviations in the health status of workers as a response of the human body systems to the complex effect of harmful factors at workplaces of underground personnel of oil mines.

Table 2

Results of risk assessment of the development of occupational diseases based on the statistical analysis of occupational diseases in underground personnel during thermal mining oil recovery

\begin{tabular}{|l|c|c|c|c|}
\hline \multicolumn{1}{|c|}{ Profession } & $\begin{array}{c}\text { Risk of workers' } \\
\text { occupational } \\
\text { disease }\end{array}$ & $\begin{array}{c}\text { Average duration } \\
\text { of service of obtaining } \\
\text { occupational disease }\end{array}$ & $\begin{array}{c}\text { Specific rate } \\
\text { of obtaining occupational } \\
\text { disease, } \%\end{array}$ & $\begin{array}{c}\text { Class of working conditions } \\
\text { according to the special } \\
\text { assessment of working } \\
\text { conditions }\end{array}$ \\
\hline Drifter & 0.0041299 & 7.5 & 2.7 & 3.3 \\
\hline Operator of a mining machine & 0.0027344 & 13.41 & 1.5 & 3.3 \\
\hline Timber man & 0.0031731 & 8.82 & 1.7 & 3.3 \\
\hline Underground miner & 0.0005212 & 31.7 & 0.5 & 3.1 \\
\hline Operator of a drill machine & 0.0025873 & 15.4 & 1.3 & 3.3 \\
\hline Operator of oil and gas production & 0.0021381 & 19.8 & 1.1 & 3.3 \\
\hline Road worker & 0.0019132 & 23.7 & 0.7 & 3.1 \\
\hline Overman & 0.0010918 & 28.1 & 0.5 & 3.1 \\
\hline Blaster & 0.0019038 & 23.4 & 0.7 & 3.1 \\
\hline
\end{tabular}


Results of the assessment of the probability of occurrence of the certain type of occupational disease depending on the duration of service

\begin{tabular}{|c|c|c|c|c|c|c|c|}
\hline \multirow{4}{*}{ Profession } & \multirow{4}{*}{$\begin{array}{c}\text { General class } \\
\text { of working } \\
\text { conditions }\end{array}$} & \multicolumn{6}{|c|}{$\begin{array}{l}\text { Probability of development of occupational diseases depending } \\
\text { on duration of service, } \%\end{array}$} \\
\hline & & \multicolumn{2}{|c|}{ vibration pathology } & \multicolumn{2}{|c|}{ pneumoconiosis } & \multicolumn{2}{|c|}{ hearing loss } \\
\hline & & \multicolumn{6}{|c|}{ service duration, years } \\
\hline & & 10 & 20 & 10 & 20 & 10 & 20 \\
\hline Drifter & 3.3 & 0.300 & 0.731 & 0.001 & 0.090 & 0.100 & 0.300 \\
\hline Operator of a mining machine & 3.3 & 0.130 & 0.306 & 0.08 & 0.400 & 0.028 & 0.096 \\
\hline Timber man & 3.3 & 0.300 & 0.623 & 0.001 & 0.070 & 0.071 & 0.100 \\
\hline Operator of a drill machine & 3.3 & 0.300 & 0.591 & 0.001 & 0.078 & 0.024 & 0.092 \\
\hline Operator of oil and gas production & 3.3 & 0.080 & 0.130 & - & - & 0.019 & 0.078 \\
\hline Support staff & 3.1 & - & - & - & - & - & 0.001 \\
\hline
\end{tabular}

Vibro-acoustic factors are the most significant: $59 \%$ of cases of occupational diseases in underground oil mine personnel, $41 \%$ due to physical overloads. At the same time, their joint effect, as well as the influence of other physical factors on a person, can lead to an increase in the negative impact and an increase in occupational pathologies. The data obtained indicate the significant role of the noise factor in the development of changes not only in auditory, but also in vibration sensitivity with the combined action of two factors. Its contribution to the magnitude of the shift threshold vibration sensitivity was $23.5 \%$. Vibration greatly enhances the adverse effects of noise on physiological parameters. An assessment of the impact of noise on underground personnel has shown that the value of the equivalent noise level for the workplace of the drifter is in the border area close to the critical. Results of the assessment of the probability of occurrence of a certain type of occupational disease, depending on the duration of service are presented in Table 3 .

The methods used to determine the occupational risk for thermal mining oil recovery of extracting oil are based on retrospective data on the impact of harmful production factors on the body of workers and are reduced to determining the probability of obtaining an occupational disease.

An analytical review of occupational diseases and working conditions of underground personnel allows to carry out risk assessment depending on the duration of service in hazardous working conditions of the Yarega oil mines.

According to the results of an assessment of the risk of occupational diseases in the professions of underground personnel, the dependences of the probability of occurrence of the disease on the length of service in working conditions in oil-mining oil. Estimation of the probability of obtaining occupational disease based on the analysis of data on occupational diseases among Yarega oil mines workers and the relative risk as well as obtained values of dependencies of occupational risk and working conditions allow to predict the probability of occupational disease for the professions of basic underground personnel depending on duration of service in hazardous working conditions. The assessment of the risk of occupational disease and the maximum allowable occupational risk for the relevant profession of underground personnel, depending on the duration of service in hazardous working conditions during thermal mining oil recovery, is presented in Fig. 1.

The uniqueness of working conditions in oil mines does not allow drawing analogies with similar industries. There is a need to develop an integrated approach to assessing the risk of occupational diseases, taking into account the influence of working conditions on the formation of professionally determined deviations in health indicators and occupational diseases of 
underground personnel at Yarega oil mines. Based on the data obtained, it is possible to give a more complete and accurate assessment of the risk of occurrence of occupational pathology. The obtained comprehensive data will allow monitoring of risk, thanks to which identify groups of workers on the risk of developing diseases in body systems and assess the effectiveness of appropriate labor protection measures will be possible at an earlier stage [2].

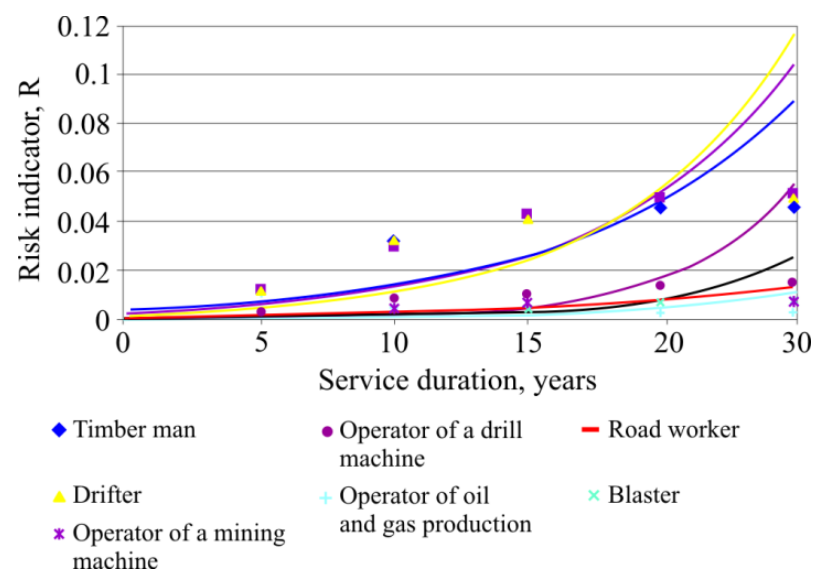

Fig. 1. Evaluation of the risk of occupational disease and the maximum permissible occupational risk for the relevant profession of underground personnel, depending on the duration of service in hazardous working conditions during thermal mining oil recovery

The working conditions at the workplaces of underground personnel engaged in the extraction of oil using the thermal mining recovery determine the list of medical specialists that workers must undergo and mandatory tests in annual medical examinations in accordance with the order of the Ministry of Health and Social Development of the Russian Federation dated April 12, 2011 No. 302n, in the sanatorium-preventorium "Shakhter" under the contract with MEDIS LLC.

There were strong medical examinations organized from 2013 taking into account the fact that the required volume of professional examination does not always allow to reveal signs at the earlier stages of the formation of occupational diseases. According to results of the analysis of the conducted periodic medical examinations 18 out of 447 underground workers of the oil mines in 2017 only were sent for further examination and counseling to decide on the presence and severity of occupational disease at the Federal State Budgetary Medical Center of the Federal Medical and Biological Agency of Russia (Moscow)

In order to obtain an objective picture of the emergence of a professional risk and the scientific substantiation of the interrelationships of working conditions, morbidity, and the dynamics of the health status of workers, the analysis of results of the occupational health personnel survey is performed [3].

Medical records of the personnel of the petroleum mines were selected in accordance with the selection criteria for detecting changes in the state of health according to professional examinations. The following groups were formed:

- employees of underground areas that are involved in the process of oil extraction by thermo-mining method (oil mines No. 1, 2, 3), the class of working conditions is harmful, degrees - 3.1-3.4.

- ground staff of workers of the AUP with a permissible class of working conditions ( $2^{\text {nd }}$ class).

The study was carried out on the following specialties: drifter, operator of a mining machine, timber man, underground miner, operator of oil and gas production, road worker, repairman, mining electric locomotive driver, mining foreman, and shaft operator. Each group was asset the most significant production risk factors [4-6].

The selection criteria were: work experience of more than 1 year and age from 18 to 55 years as well as the passage of military service.

The group under the study (drifter, operator of a mining machine, timber man, operator of oil and gas production and operator of a drill machine) included 150 men with average age of $41.94 \pm 9.68$ years, average duration of service $-11.23 \pm 1.52$ years old), a comparison group (underground miner, road worker, mechanic, blaster, a mining foreman, mining electric locomotive driver and shaft operator) 180 men (average age $42.34 \pm 11.36$ years, average duration of service $-13.20 \pm 9.18$ years). 
The reference group - 30 men from the management division (average age $44.23 \pm 12.61$ years, average duration of service $14.32 \pm 10.19$ years).

Evaluation of the impact on personnel of environmental factors, such as poor ecology, smoking and alcohol consumption, showed that during the last 12 months, $78.9 \%$ of respondents consumed alcoholic beverages with different frequency (in the observation group $-75.8 \%$, in the comparison group $-87 \%$ ). There were no statistically significant differences in the effect of the external environment in the groups $(p>0.05)$.

The impersonal data of the results of examinations from the medical records of the oil mines staff is entered into the electronic database and evaluated to obtain changes in the causal relationship of working conditions with impairment of health and occupational morbidity. Each examined employee was assigned an individual number in accordance with the requirement of personal data protection.

In order to study the changes in the state of health of the personnel, the results of the passage of medical specialists and laboratory and functional studies of 360 employees (men) of oil mines were analyzed.

The complex contribution of exposure to harmful factors is reflected in the risk of the formation of certain diseases, which can be grouped into the following groups: vibration disease, hearing loss, respiratory diseases, cardiovascular disorders, and diseases of the musculoskeletal system. Characteristics of groups of occupational diseases are given in Table 4.
Skin diseases are not counted due to the lack of analyzed data, except for a mark about a visual examination of a dermatologist in the medical record. Diseases of the musculoskeletal system, namely chronic radiculopathy (lumbosacral, cervical), are registered according to the complaints of employees to a specialist (a therapist). People with similar complaints are sent for further in-depth medical examination. Only the numerical results of medical examinations by specialist doctors and laboratory and functional studies were processed. It took into account general information about the employee, such as age, work experience in the profession, the presence of bad habits and service in the armed forces. The results of fluorography, urinalysis and ultrasound were not considered. The analysis of the results of the personnel mine screening showed that the risk factors for the development of diseases and their complications are presented in almost $77.4 \%$ of those examined, and $30 \%$ have primary signs of at least one disease. For underground personnel, not only the development of a single occupational disease is likely, but also a combination of occupational pathologies due to the complex effects of harmful production factors.

The next stage of the study involved the analysis and evaluation of the formation of outcomes. Under the outcome implied one or another disease, which was formed in an employee at risk in the process of dynamic observation. In the study group, the main occupations and the most important production risk factors are identified. We will establish a closer link between the development of diseases and working conditions and estimate the risk of their development depending on the length of service.

Table 4

Groups of occupational diseases

\begin{tabular}{|l|c|c|}
\hline \multicolumn{1}{|c|}{ Group of occupational diseases } & Medical examination by specialists & Laboratory and functional studies \\
\hline Vibration disease & $\begin{array}{c}\text { Therapist, ophthalmologist, } \\
\text { neurologist }\end{array}$ & $\begin{array}{c}\text { Vibration sensitivity; } \\
\text { cold test, dynamometry }\end{array}$ \\
\hline Hearing loss & Therapist, otorhinolaryngologist & Audiogram, acumetry \\
\hline Respiratory diseases & Therapist & Spirometry \\
\hline Violations of the cardiovascular activity & Therapist & $\begin{array}{c}\text { Electrocardiography, clinical, } \\
\text { biochemical analysis of blood }\end{array}$ \\
\hline
\end{tabular}


The analysis of the results of audio grams and acoumetry made it possible to determine the degree of hearing impairment depending on the length of service and dose. The study showed that the risk of hearing loss in staff at the site of oil drilling and production, the average work experience for underground workers is the following: initial level of hearing impairment $5.5 \pm 2.1$; moderate $-8.9 \pm 2.3$; light $-12.4 \pm 5.8$, severe $-19.4 \pm 9.1$. The average work experience for underground personnel without hearing impairment is $7.3 \pm 1.2$ years, and the probable range of the most probable disease registration is from 10 to 28 years. According to the results of the research, it was established that a professional hearing loss develops with a timber man and operator of a drill machine with less work experience than that of a mining excavator machine operator and operator of oil and gas production. A study of hearing impairment showed that the main group of individuals is at risk of hearing loss.

For the drifter, timberman, operator of a mining machine and operator of a drill machine the local vibration is an aggravating factor.

In the case of a combined vibration, a combination of syndromes characteristic of both local and general vibration effects takes place. Employees of these professions take strong medical examination. The data from functional studies of vibration sensitivity, cold test and dynamometry were used to assess the occurrence of vibration disease.

The results of the medical examination of underground personnel engaged in working with vibrotools showed that with less than 3 years work experience there was no change in the vibration sensitivity threshold, with an experience of 5 to 7 years, the excess was $55.2 \%$, with an experience of 7-10 years $76.8 \%$, and with the experience of more than 10 years - up to $100 \%$. The average time of occurrence of vibration disease in underground personnel is $8.4 \pm 1.9$ years.

The data obtained indicate that there is a direct correlation between the growth of the vibration sensitivity threshold and professional experience. Primary changes in vibration sensitivity are observed in $37.9 \%$ of those surveyed with an experience of 3 years, in $87.4 \%$ of workers with an experience of 5 years. The threshold of vibration sensitivity increased with the growth of clinical manifestations of vibration disease.

Clinical manifestations of sensory polyneuropathy of the upper extremities are moderately expressed, and may be accompanied by vegetative-trophic disorders. Perhaps a combination of sensory polyneuropathy with syndromes of the lesion of the musculoskeletal system, especially if the effects of local vibration combined with physical stress on the upper limbs.

The obtained values of the risk of the development of vibration pathologies correspond to the values of the occupational risk obtained as a result of using various methods for assessing working conditions and analyzing occupational diseases. Thanks to the laboratory and functional studies carried out as part of a strong professional examination, it is possible to establish the level of exposure to local vibration, which allows early detection of abnormalities in health status.

The analysis of the results of professional examinations showed that the proportion of signs of vibration on the upper limbs was about $82.9 \%$, the proportion of preliminary diagnoses $-17.1 \%$.

Comprehensive data allows you to monitor the risk of occurrence of vibration disease and make a predictive assessment for the development of measures aimed at reducing the triggering factors. The risk management system should be based not only on the assessment of the production factor or working conditions in general, but also on the results of occupational examinations [7-9].

An analysis of the results of spirometry showed that dust diseases of the lung dust etiology occur in $12.9 \%$ of underground workers engaged in sinking and expanding mine workings with experience of more than 15 years, and they are classified as a slowly progressing form of pneumoconiosis. Pneumoconiosis proceed 
without disturbing the function of external respiration at early stages often. The results of the study are as follows: in $56 \%$ of persons, the indicators are normal; $24 \%$ have slight violations of the diffusion capacity of the lungs (DLCO $80 \pm 5 \%$ ); in $20 \%$ of the diffusion capacity is moderately reduced (DLCO $-60 \pm 5 \%$ ).

Analysis of the results of an electrocardiogram (ECG), general clinical, biochemical blood tests showed that $37.34 \%$ of workers had a periodic increase in blood pressure (labile and systolic and diastolic arterial hypertension), they are in the risk group on the development of arterial hypertension. The results of the clinical and functional examination of underground personnel and persons working in the management apparatus, differing in age and length of service testify to significant differences in the state of their cardiovascular system, which depend not only on age, but also on their profession and experience.

According to the medical records, the mean pressure values of the oil shafts workers were established: mean systolic blood pressure (SBP) $136.4 \pm 11.3 \mathrm{~mm} \mathrm{Hg}$, mean diastolic blood pressure (DBP) $-87.1 \pm 7.8 \mathrm{~mm} \mathrm{Hg}$, the average pulse blood pressure $-767 \pm 4.1 \mathrm{~mm} \mathrm{Hg}$. Employees of the comparison group (AUP) were not exposed to harmful production factors, they have the following average values: $\mathrm{SBP}-140.2 \pm 5.1 \mathrm{~mm}$ $\mathrm{Hg}, \mathrm{DBP}-96.2 \pm 4.2 \mathrm{~mm} \mathrm{Hg}$, the average pulse blood pressure - $64 \pm 4.5 \mathrm{~mm} \mathrm{Hg}$. The significance of differences between groups $p<0.001$. High blood pressure was established in $52.0 \%$ of the persons of the mining subgroup and the miners of the $2^{\text {nd }}$ group; in $56.3 \%$ of persons from the drifting subgroup, in the group of support staff - in $22 \%$, in the comparison group $3 \%$. The average heart rate was $79 \pm 7.4 \mathrm{bpm}$, normal heart rate was observed in $56.9 \%$ of all underground workers, sinus bradycardia in 15.0 $\%$, sinus arrhythmia in $10.2 \%$, sinus tachycardia in $5.5 \%$, ectopic lower atrial rhythm - in $9.5 \%$. The values of blood pressure in excess of $140 / 90 \mathrm{~mm} \mathrm{Hg}$, on average, set in $39.8 \%$ of cases for SBP and in $46.5 \%$ for DBP. 68 people from the entire underground group of blood pressure exceeded the norm by $42 \%$, which is considered to be particularly unfavorable. These personnel may be assigned to the risk group for the occurrence of cardiovascular diseases.

The analysis of ECG results given above allows to determine the pattern of changes in various indicators and showed their diagnostic significance with increasing length of service and age of the employee.

Changes in blood biochemical parameters characterize the initial stage of impaired activity of the cardiovascular system in underground workers. The most significant indicator for the development of cardiovascular diseases is an increase in total cholesterol levels. Evaluation of the results of the general and biochemical blood test was carried out in groups of individuals united by work experience: up to 5 years $-8 \%$ of those examined, $5-10$ years $-11.3 \%$, and more than 10 years $-25 \%$. It was found that with increasing length of service, cholesterol levels increase.

The average values of total cholesterol, $\mathrm{mol} / \mathrm{l}$, among workers of oil mines were distributed as follows:

- for core group $-5.87 \pm 0.18$;

- for support staff $-5,24 \pm 0,8$;

- for persons from the comparison group (AUP) $-4.96 \pm 0.13$, while the standart/pathology ratio was 3.88/8.02.

The average value of total cholesterol in the main group exceeds that of support staff by $11 \%$, and in the comparison group by $26 \%$. Significant differences were obtained in terms of total cholesterol between groups of oil mines personnel $(p<0.05)$. The results of the study indicate an average risk of developing cardiovascular pathologies.

Evaluation of the health status of the studied blood parameters did not reveal statistically significant differences between the groups, their values within the physiological norm. When studying the role of harmful factors in the formation of diseases in the underground personnel of the oil mines, it was found that the working conditions for the thermo-mining method of oil production significantly affect the development of cardiovascular diseases. 
Evaluation of the results of professional examinations showed a very high degree of influence of production conditions on the musculoskeletal system, while the share of vibration diseases in the main group was 71.2-82.1 \%. The influence of working conditions on the organs of hearing in the studied group is also high (55.9-64.2 \%). Deviations in the cardiovascular system have an average degree of production conditionality with an etiological share of $34.2-47.5 \%$. Deviations in the respiratory system (etiological share - 32.7-45.4\%) are moderately due to production.

The established degree of industrial conditionality of violations in the health systems of oil mines workers depending on the profession, working conditions and professional experience allowed us to calculate the risks of a certain type of occupational disease. As a result, the dependence of violations of personnel health systems and types of occupational diseases on the length of service in harmful working conditions of the oil mines of the Yarega field was obtained. The Fig. $2 a$ shows relative risk of production-related violations and occupational diseases, depending on the length of service of underground personnel in hazardous working conditions of the Yarega oil mines [10-13].

The analysis of the results of the evaluation of the professional risk confirmed that the degree of production conditionality of violations in the body systems of workers depends on the class of chronic diseases, working conditions and profession [14-17]. The risk assessment showed an almost complete and very high degree of production conditionality of vibration pathology and diseases of the organs of hearing for the main group of underground personnel with an etiological share of 72.2-81.1\%, meaning a very strong connection with working conditions. At the same time, diseases of the cardiovascular system and respiratory organs have the high degree of production conditionality with an etiological share of 54.5-62.9 \% and are characterized by a strong connection with working conditions.
The analysis of the results showed a very high and high degree of production of the health condition of drifters [18-21], operator of a mining machine and timber man with reliable relative risk indicators: 2.1 - oil and gas production operator, 2.8 - drilling rig operator, 2.9 - timber man, 3.0 - operator of a mining machine; 3,1 - drifters. The etiological share is $64.2-67.7 \%$, the class of working conditions is 3.3, which indicates the significant role of working conditions in the formation of impairments in health systems. At the same time, health systems with an etiological share of factors of $37.5-50.0 \%$, reliable relative risk indicators 1.6-2.0 and a class of working conditions 3.1-3.2 for a road worker, underground miner, blaster, overman. A low degree of industrial conditional impairment of health systems with the etiological share of facts 15.7-30.0\%, reliable relative risk indicators of 0.6-1.4, and classes of working conditions 3.1 was established for the underground locksmith, the mine and shaft locomotive driver.

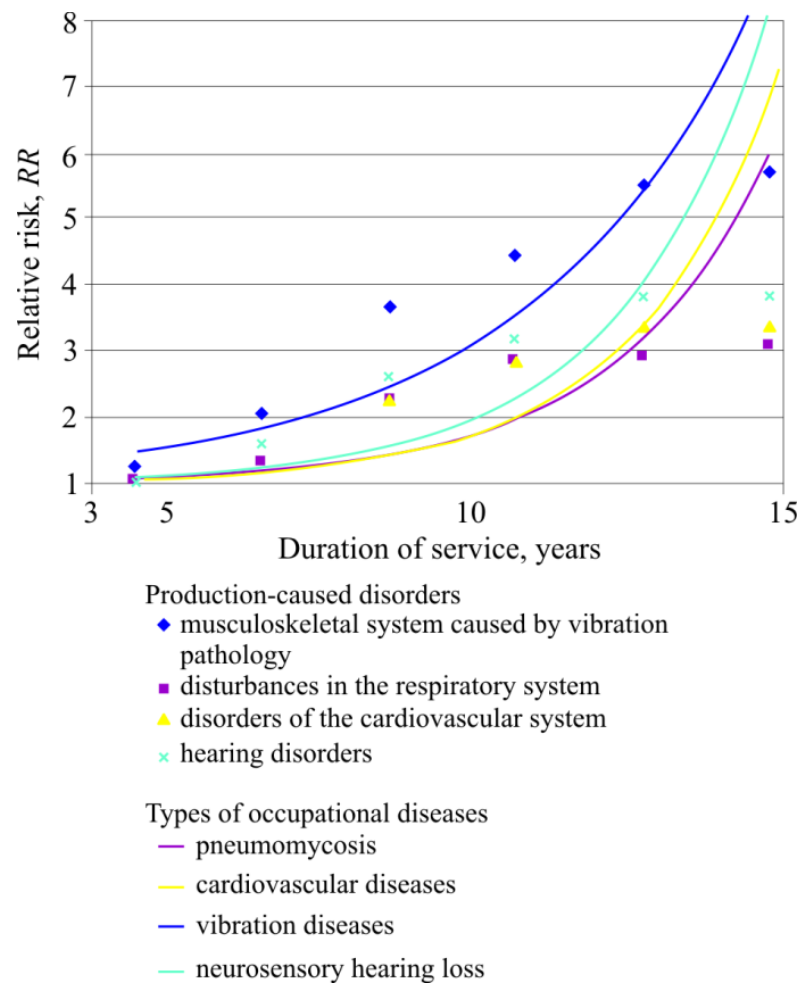

Fig. 2. Dependence of production-related violations and occupational diseases on the duration of service of underground personnel in hazardous working conditions of Yarega oil mines 


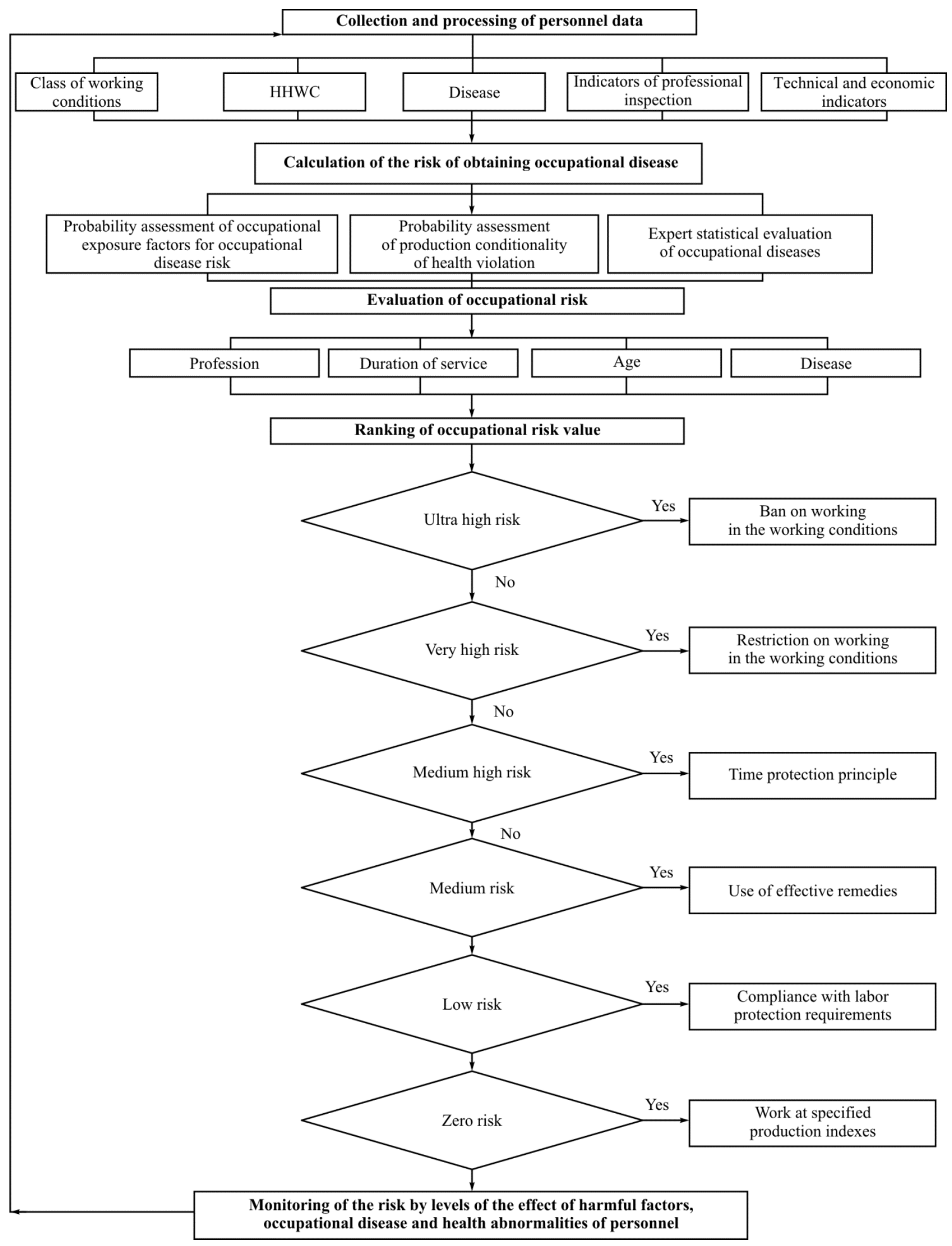

Fig. 3. The algorithm of the combined risk assessment of the receipt and development of occupational diseases with ranking criteria for the system of labor protection management during the thermal mining oil recovery 
The results of the evaluation of the risk of getting the disease depending on the degree of production conditionality showed that the higher the class of harmful working conditions, the greater the degree of production conditionality of the development of pathology [22-25]. The results can be used in the monitoring system of health, working conditions and occupational morbidity for the management of professional risks and the assessment of the effectiveness of measures taken in the system of occupational safety of oil mines [26-28]. The results of the study allow us to develop risk assessment maps for occupational diseases depending on the profession, length of service, working conditions, the degree and probability of exposure to harmful factors, and the type of occupational disease for the main and auxiliary underground personnel involved in the oil production by the thermal mining oil recovery.

In order to identify the relationship of working conditions with production processes, an algorithm is proposed for a comprehensive assessment of the risk of exposure to levels of harmful factors and the development of production-related deviations in health status and cases of occupational diseases (Fig. 3) [29-36].

\section{Conclusions}

1. Analysis of occupational diseases in the coal, oil mine and oil producing industries of the Komi Republic for 2000-2016 shows that the occurrence of occupational diseases is associated with the influence of the prevailing harmful factors. The risk group for obtaining occupational pathology includes workers who are involved in the section of penetration and expansion of mine workings. The staff works with the use of vibration-generating tools $-75.6 \%$, heavy physical labor $-61.2 \%$, when exposed to noise $-84.7 \%$. For workers in the petroleum industry, occupational diseases are prioritized as follows: vibration sickness, chronic lumbosacral radiculopathy, chronic neurosensory hearing loss and the only case of reflex myotonic syndrome.

The review of working conditions showed that the majority of jobs at Yarega oil mines belong to the class with hazardous working conditions
(82 \%), i.e. can cause occupational diseases. Subclasses 3.1 and 3.3 (45 and $33 \%$ respectively) prevail, which corresponds to a very high degree of professional risk. We note the conditionality of the occurrence of certain forms of disease in the workplaces of underground personnel in oil mines by harmful and dangerous production factors.

According to the results of the research, it is concluded that it is necessary to conduct a comprehensive assessment of the risk of occupational morbidity in conjunction with working conditions and production-related deviations in the state of health of the underground personnel involved in thermal mining oil recovery.

2. The expert-statistical assessment method was used during the assessment of the risk of occupational diseases in the underground personnel of the Yarega oil mines. The risk assessment carried out does not take into account changes in the state of health of the personnel, but only the probability of obtaining occupational disease, the fact of obtaining occupational disease and work experience in hazardous working conditions are recorded. The methods used to determine the occupational risk for the thermal mining oil recovery are based on retrospective data on the impact of harmful production factors on the body of workers and are reduced to determining the probability of obtaining an occupational disease. For the more accurate assessment of the level of occupational risk for the health of underground personnel, an occupational risk assessment system is needed, which would take into account working conditions, occupational morbidity and deviations in the health status of workers as a response of the human body systems to the complex effect of occupational hazard levels.

3. Studies of deviations in the health status of the main group of underground workers at Yarega oil mines showed a very high degree of production of diseases of the musculoskeletal system with an etiological share of vibration diseases 71.2-82.1\%, which indicates a very strong relationship with working conditions. Hearing diseases in the studied group also have a strong connection with 
working conditions and the high degree of production conditionality with an etiological share of 55.9-64.2\%. Deviations in the cardiovascular system are characterized by an average relationship with working conditions, have the average degree of industrial conditionality with the etiological share of 34.2-47.5\%. Deviations in the respiratory system with the etiological share of $32.7-45.4 \%$ are attributed to the average degree of production condition.

4. The analysis of the results of the assessment of the production conditionality of health disorders confirms the dependence on the profession, working conditions, work experience and showed a very high and high degree of production conditionality of the health state of the drifters, machinists of mining excavation machines and rigging with reliable relative risk indicators for the operator of oil and gas production - 2.1, operator of a drill rig - 2.8, timberman - 2.9, operator of a mining machine -3.0 , drifter -3.1 with an etiological share 64.2-67.7 \% and classes of working conditions 3.3, which indicates about the significant role of working conditions in the formation of violations in health systems. At the same time, health systems with an etiological share of factors of 37.5-50.0\%, reliable relative risk indicators $1.6-2.0$ and the class of working conditions 3.1-3.2 for a road worker, underground miner, blaster and supervisor. A low degree of production conditionality of health system disorders with an etiological share of facts 15.7-30.0\%, reliable relative risk indicators of 0.6-1.4 and working conditions 3.1 classes falls on the mechanic, electric locomotive and shaft operator. The studies showed the importance of the "dose-experience-effect" relationship for the emergence of production-related deviations in the state of health, leading to the occurrence of occupational disease among underground personnel.

5. The analysis of the results of medical and social research showed that a comprehensive assessment of the indicators of the occurrence of the disease depending on the profession and work experience is necessary. The need to improve the system of accounting, monitoring of occupational diseases and analyzing the effectiveness of measures taken to preserve the life and health of oil mines personnel was noted. To solve the problems associated with the reduction of violations and complications in the health status of occupational diseases, it is necessary to substantiate and implement an adequate organizational and functional model for assessing the risk of occupational disease.

\section{References}

1. Grunskoy T.V., Perkhutkin V.P., Berdnik A.G. Analiz i otsenka professionalnykh zabolevaniy podzemnogo personala na nefteshakhtakh Yaregskogo mestorozhdeniya [Analysis and assessment of professional diseases of underground personnel on oil-stores of Yaregsk place of birth]. Neftegazovoe delo, 2017, no.3, pp.128-144. DOI: 10.17122/ogbus-2017-3-128-144

2. Grunskoy T.V., Perkhutkin V.P., Berdnik A.G. Analytical review of working conditions of underground personnel in the oil mines of the Yaregskoe field. Perm Journal of Petroleum and Mining Engineering, 2017, vol.16, no.4, pp.378-390. DOI: $10.15593 / 2224-9923 / 2017.4 .9$

3. Grunskoy T.V., Perkhutkin V.P. Ustanovlenie vzaimosvyazey usloviy truda $\mathrm{s}$ proizvodstvennymi protsessami pri intensifikatsii prokhodcheskikh rabot $\mathrm{v}$ neftyanykh shakhtakh Yaregskogo mestorozhdeniya [Interconnection of working conditions with production processes when improving tunnel works in yaregskoye field oil mines]. Neftegazovoe delo, 2013, no.2, pp.184-193.
4. Grunskoy T.V., Perkhutkin V.P. Sovershenstvovanie metodologii otsenki usloviy truda pri intensifikatsii prokhodcheskikh rabot $\mathrm{V}$ neftyanykh shakhtakh Yaregskogo mestorozhdeniya [Improving the methodology for assessing working conditions during the intensification of tunnel works in oil shafts of the Yarega field]. Promyshlennaya bezopasnost mineralno-syrevogo kompleksa $v$ XXI veke: Gornyy informatsionnoanaliticheskiy byulleten, 2015, no.2, iss.7. Moscow, Gornaya kniga, $816 \mathrm{p}$.

5. Grunskoy T.V., Perkhutkin V.P. Upravlenie bezopasnostyu truda $\mathrm{V}$ usloviyakh intensifikatsii prokhodcheskikh rabot $\mathrm{V}$ neftyanykh shakhtakh Yaregskogo mestorozhdeniya [Labour safety management in the context of intensified sinking operations at Yaregskaya oil-field's mines]. Uchenye zapiski KNAGTU, 2013, no.4, pp.101-109.

6. Grunskoy T.V., Perkhutkin V.P. Sovershenstvovanie informatsionnogo obespecheniya sistemy upravleniya bezopasnostyu truda prokhodcheskikh rabot $\mathrm{V}$ 
nefteshakhtakh Yaregskogo mestorozhdeniya [Improving the information support of the occupational safety management system of tunneling in the oil mines of the Yarega field]. Neftegazovoe delo, 2014, no.2, pp.392-406. DOI: 10.17122/ogbus-2014-2-392-406

7. Grunskoy T.V., Kaplina M.V., Sokhodon G.V. Otsenka tyazhesti i napryazhennosti truda na rabochikh mestakh podzemnogo personala Yaregskikh nefteshakht [Assessment of the severity and intensity of work in the workplaces of underground personnel at Yarega Nefeshakht]. Resursy Evropeyskogo Severa. Tekhnologii $i$ ekonomika osvoeniya, 2017, no.3, pp.35-55.

8. Grunskoy T.V., Perkhutkin V.P. Upravlenie bezopasnostyu trudovogo protsessa prokhodki gornykh vyrabotok v neftyanykh shakhtakh Yaregskogo mestorozhdeniya [Safety management of the labor process of mining in the oil shafts of the Yarega field]. Resursy Evropeyskogo Severa. Tekhnologii i ekonomika osvoeniya, 2017, no.1, pp.10-22.

9. Grunskoy T.V. Puti i sposoby realizatsii politiki kompanii razvitiya nefteshakhtnogo proizvodstva [Ways and means of implementing the policy of the company's development of oil mine production]. Nauchnyy vzglyad na sovremennyy etap razvitiya obshchestvennykh, tekhnicheskikh, gumanitarnykh $i$ estestvennykh nauk. Aktualnye problem. Sbornik nauchnykh statey po itogam vserossiyskoy nauchno-prakticheskoy konferentsii. Saint Petersburg, Sankt-Peterburgskiy institut proektnogo menedzhmenta, 2014, p.35.

10. Grunskoy T.V. Fotografiya rabochego vremeni prokhodchika nefteshakhty Yaregskogo mestorozhdeniya [Photo of working hours of an oil miner of the Yaregskoye field]. Severgeoekotekh-2012. Sbornik materialov XIII mezhdunarodnoy molodezhnoy nauchnoy konferentsii. Ukhta,2012, pp.162-167.

11. Grunskoy T.V. Metodika kompleksnoy otsenki usloviy truda pri modernizatsii prokhodcheskikh rabot $\mathrm{v}$ nefteshakhtakh Yaregskogo mestorozhdeniya [Methods of comprehensive assessment of working conditions during the modernization of tunnel works in the oil mines of the Yarega field]. Severgeoekotekh-2013. Sbornik materialov XIV mezhdunarodnoy molodezhnoy nauchnoy konferentsii, Ukhta, 2013, pp.217-219.

12. Grunskoy T.V. Ustanovlenie vzaimosvyazey trudovogo protsessa $\mathrm{s}$ vrednymi faktorami $\mathrm{v}$ usloviyakh modernizatsii prokhodcheskikh rabot $\mathrm{V}$ neftyanykh shakhtakh Yaregskogo mestorozhdeniya [Establishment of the relationship of the labor process with harmful factors in the conditions of modernization of tunnel works in the oil mines of the Yarega field]. Severgeoekotekh2013. Sbornik materialov XIV mezhdunarodnoy molodezhnoy nauchnoy konferentsii. Ukhta, 2013, pp.224-227.
13. Grunskoy T.V., Perkhutkin V.P. Identifikatsiya opasnykh i vrednykh faktorov rabochikh mest nefteshakht Yaregskogo mestorozhdeniya [Identification of hazardous and harmful factors of workplaces oil mine of the Yarega field]. Severgeoekotekh-2011. Materialy XII Mezhdunarodnoy molodezhnoy nauchnoy konferentsii, 16-18 marta 2011 g. Ukhta, 2011, part 4, pp.283-285.

14. Grunskoy T.V., Perkhutkin V.P. Istoricheskiy obzor usloviy truda rabotayushchego personala nefteshakht Yaregskogo mestorozhdeniya mestorozhdeniya [Historical overview of the working conditions of the working personnel of the Nefteshakht Yaregskoye field]. Severgeoekotekh-2011. Materialy XII Mezhdunarodnoy molodezhnoy nauchnoy konferentsii, 16-18 marta 2011 g. Ukhta, 2011, part 4, pp.279-282.

15. Grunskoy T.V., Perkhutkin V.P. Raschet energozatrat personala pri vypolnenii prokhodcheskikh rabot $\mathrm{v}$ nefteshakhtakh Yaregskogo mestorozhdeniya [Calculation of energy consumption of personnel when performing tunnel works in oil mines of the Yaregskoye field] Sbornik nauchnykh trudov. Materialy nauchnotekhnicheskoy konferentsii, 20-23 sentyabrya $2011 \mathrm{~g}$. Ukhta, 2011, part 1, pp.317-321.

16. Grunskoy T.V., Perkhutkin V.P. Prognozirovanie parametrov sostoyaniya proizvodstvennoy sredy $\mathrm{v}$ nefteshakhte Yaregskogo mestorozhdeniya [Prediction of the parameters of the state of the production environment in the oil mine of the Yaregskoye field]. Sbornik nauchnykh trudov. Materialy nauchno-tekhnicheskoy konferentsii, 20-23 sentyabrya 2011 g. Ukhta, 2011, part 1, pp.322-325.

17. Grunskoy T.V., Perkhutkin V.P. Sravnitelnaya otsenka effektivnosti metodov prokhodcheskikh rabot $\mathrm{v}$ nefteshakhte Yaregskogo mestorozhdeniya [Comparative evaluation of the efficiency of tunneling methods in the oil mine of the Yaregskoye field]. Sbornik nauchnykh trudov. Materialy nauchno-tekhnicheskoy konferentsii, 16-19 aprelya 2013 g. Ukhta, Ukhtinskiy gosudarstvennyy tekhnicheskiy universitet, 2013, part 1, pp.320-323.

18. Nor E.V. Prognoznaya otsenka pylegazovogo rezhima vozdukha rabochikh zon neftyanykh shakht pri parateplovom vozdeystvii na plast (na primere Yaregskogo mestorozhdeniya vysokovyazkoy nefti) [Predictive assessment of the dust-gas regime of the air in the working areas of oil mines with para-thermal effects on the formation (on the example of the Yarega deposit of high-viscosity oil)]. Ph. D. thesis. Ukhta, 2004, $130 \mathrm{p}$.

19. Novikov S.M. Otsenka riska dlya zdorovya. Algoritm rascheta doz pri otsenke riska, obuslovlennogo mnogosredovymi vozdeystviyami khimicheskikh veshchestv [Health risk assessment. Dose calculation algorithm for risk assessment caused by multi-medium chemical exposures]. Moscow, 1999, 51 p. 
20. Novikov S.M., Avaliani S.L., Bushtueva K.A. Otsenka riska dlya zdorovya. Opyt primeneniya metodologii otsenki riska $v$ Rossii [Health risk assessment. Experience of applying risk assessment methodology in Russia]. Moscow, 1999, 290 p.

21. Analiz i upravlenie riskom: teoriya i praktika [Analysis and risk management: theory and practice]. Moscow, Strakhovaya gruppa "LUKOYL", 2016, 186 p.

22. Izmerov N.F., Denisov E.I., Molodkina N.N. et al. Metodologiya otsenki professionalnogo riska $\mathrm{v}$ meditsine truda [Methodology of occupational risk assessment in occupational medicine]. Meditsina truda i promyshlennaya ekologiya, 2001, no.12, pp.1-7.

23. Khasanova A.A., Shur P.Z., Shlyapnikov D.M. Otsenka izmeneniy funktsiy organizma pod vliyaniem usloviy professionalnoy deyatelnosti [Methodology of occupational risk assessment in occupational medicine]. Vestnik Permskogo universiteta, 2014, iss.2, pp.48-51.

24. Gladkova L.A., Zuev B.Yu., Istomin R.S., Loginov M.A. Analiz sovremennykh metodov i sredstv monitoringa pri podzemnoy razrabotke poleznykh iskopaemykh [Analysis of modern methods and means of monitoring in underground mining of minerals]. Gornyy informatsionno-analiticheskiy byulleten, 2010, no.4, pp.19-24.

25. Khenli D., Kumamoto Kh. Nadezhnost tekhnicheskikh sistem i otsenka riska [Reliability of technical systems and risk assessment]. Moscow, Mashinostroenie, 1984, $528 \mathrm{p}$.

26. Elokhin A.N. Analiz i upravlenie riskom: teoriya i praktika [Analysis and Risk Management: Theory and Practice]. Moscow, Strakhovaya gruppa "LUKOYL", 2010, 186 p.

27. Malyshev D.V. Analiz sistem upravleniya promyshlennoy bezopasnostyu, okhranoy truda $\mathrm{v}$ RF i zarubezhnykh neftegazovykh kompaniyakh [Analysis of industrial safety and labor safety management systems in the Russian Federation and foreign oil and gas companies]. Aktualnye problemy sostoyaniya i razvitiya neftegazovogo kompleksa rossii. Tezisy dokladov 5 nauchno-tekhnicheskoy konferentsii. Moscow, RGU nefti i gaza imeni I.M. Gubkina, 2003, p.6.

28. Gorskaya T.V. Otsenka usloviy truda v metallurgii s uchetom sochetannogo vozdeystviya vrednykh proizvodstvennykh faktorov [Assessment of working conditions in metallurgy taking into account the combined effect of harmful production factors]. Ph. D. thesis. Moscow, 2007, 148 p.

29. Dolyatovskiy V.A., Dolyatovskaya V.N. Issledovanie sistem upravleniya [Management systems research]. Moscow, Mart, 2003, 256 p.

30. Mukminov R.A., Gallyamov M.A. Matematicheskoe modelirovanie protsessov okhrany truda [Mathematical modeling of labor protection processes]. Ufa, Ufimskiy neftyanoy institut, 1990, $74 \mathrm{p}$.

31. Serbinovskiy B.Yu., Rudik E.V. Monitoring proizvoditelnosti truda [Work productivity monitoring]. Novocherkassk, LIK, 2010, 260 p.

32. Yang S. Sistemnoe upravlenie organizatsiey [System management of organization]. Moscow, Sovetskoe radio, 1972, $456 \mathrm{p}$.

33. Practical tools and checklists for risk assessment. Prilozhenie 1. Instrument otsenki riskov. Evropeyskoe agentstvo po obespecheniyu zdorovya i bezopasnosti rabotnikov. Bilbao, 2007.

34. Principles for the assessment of risks to human health from exposure to chemicals. Environmental Health Criteria 210. Geneva, WHO, 1999, available at: http://www.inchem.org/documents/ehc/ehc/ehc210.htm (accessed: 12 June 2018).

35. Shimizu Y., Kato H., Schull W.J. Studies of the mortality of a-bomb survivors: 9. Mortality, 1950-1985: Part 2. Cancer mortality based on the recently revised doses (DS86), vol.121, no.2, pp.120-141. DOI: $10.2307 / 3577495$

36. Sources, effects and risk of ionizing radiation. Report. United National Scientific Committee on the Effects of Atomic Radiation (UNSCEAR). Vein, 2000.

\section{Библиографический список}

1. Грунской Т.В., Перхуткин В.П., Бердник А.Г. Анализ и оценка профессиональных заболеваний подземного персонала на нефтешахтах Ярегского месторождения // Нефтегазовое дело. - 2017. - № 3. C. 128-144. DOI: 10.17122/ogbus-2017-3-128-144

2. Грунской Т.В., Перхуткин В.П., Бердник А.Г. Аналитический обзор условий труда подземного персонала нефтяных шахт Ярегского месторождения // Вестник Пермского национального исследовательского политехнического университета. Геология. Нефтегазовое и горное дело. - 2017. - Т. 16, № 4. - C. 378-390. DOI: 10.15593/2224-9923/2017.4.9
3. Грунской Т.В., Перхуткин В.П. Установление взаимосвязей условий труда с производственными процессами при интенсификации проходческих работ в нефтяных шахтах Ярегского месторождения // Нефтегазовое дело. - 2013. - № 2. - С. 184-193.

4. Грунской Т.В., Перхуткин В.П. Совершенствование методологии оценки условий труда при интенсификации проходческих работ в нефтяных шахтах Ярегского месторождения // Промышленная безопасность минерально-сырьевого комплекса в XXI веке: Горный информационноаналитический бюллетень (научно-технический 
журнал). 2015. - № 2 (спец. вып. 7). - М.: Горная книга. -816 с.

5. Грунской Т.В., Перхуткин В.П. Управление безопасностью труда в условиях интенсификации проходческих работ в нефтяных шахтах Ярегского месторождения // Ученые записки КНАГТУ. - 2013. № 4. - С. 101-109.

6. Грунской Т.В., Перхуткин В.П. Совершенствование информационного обеспечения системы управления безопасностью труда проходческих работ в нефтешахтах Ярегского месторождения // Нефтегазовое дело. - 2014. - № 2. - С. 392-406. DOI: 10.17122/ogbus-2014-2-392-406

7. Грунской Т.В., Каплина М.В., Соходон Г.В. Оценка тяжести и напряженности труда на рабочих местах подземного персонала Ярегских нефтешахт // Ресурсы Европейского Севера. Технологии и экономика освоения. - 2017. - № 3. - С. 35-55.

8. Грунской Т.В., Перхуткин В.П. Управление безопасностью трудового процесса проходки горных выработок в нефтяных шахтах Ярегского месторождения // Ресурсы Европейского Севера. Технологии и экономика освоения. - 2017. - № 1. C. $10-22$.

9. Грунской Т.В. Пути и способы реализации политики компании развития нефтешахтного производства // Научный взгляд на современный этап развития общественных, технических, гуманитарных и естественных наук. Актуальные проблемы: сб. науч. ст. по итогам Всерос. науч.-практ. конф. / Санктпетербургский институт проектного менеджмента. СПб., 2014. - С. 35.

10. Грунской Т.В. Фотография рабочего времени проходчика нефтешахты Ярегского месторождения // Севергеоэкотех-2012: сб. материалов XIII Междунар. молодежной науч. конф.: в 6 ч. - Ухта, 2012. - Ч. 5. C. $162-167$.

11. Грунской Т.В. Методика комплексной оценки условий труда при модернизации проходческих работ в нефтешахтах Ярегского месторождения // Севергеоэкотех-2013: сб. материалы XIV Междунар. молодежной науч. конф.: в 5 ч. - Ухта, 2013. - Ч. 4. C. 217-219.

12. Грунской Т.В. Установление взаимосвязей трудового процесса с вредными факторами в условиях модернизации проходческих работ в нефтяных шахтах Ярегского месторождения // Севергеоэкотех-2013: сб. материалов XIV междунар. молодежной науч. конф.: в 5 ч. - Ухта, 2013. - Ч. 4. - С. 224-227.

13. Грунской Т.В., Перхуткин В.П. Идентификация опасных и вредных факторов рабочих мест нефтешахт Ярегского месторождения // Севергеоэкотех-2011: материалы XII Междунар. молодежная науч. конф., 16-18 марта 2011 г.: в 5 ч. Ухта, 2011. - Ч. 4. - С. 283-285.

14. Грунской Т.В., Перхуткин В.П. Исторический обзор условий труда работающего персонала нефтешахт Ярегского месторождения месторождения // Севергеоэкотех-2011: материалы XII Междунар. молодежная науч. конф., 16-18 марта 2011 г.: в 5 ч. Ухта, 2011. - Ч. 4. - С. 279-282.

15. Грунской Т.В., Перхуткин В.П. Расчет энергозатрат персонала при выполнении проходческих работ в нефтешахтах Ярегского месторождения // Сб. науч. тр.: материалы науч.-техн. конф. (20-23 сентября 2011 г.). - Ухта, 2011. - Ч. 1. - С. 317-321.

16. Грунской Т.В., Перхуткин В.П. Прогнозирование параметров состояния производственной среды в нефтешахте Ярегского месторождения // Сб. науч. тр.: материалы науч.-техн. конф. (20-23 сентября 2011 г.). - Ухта, 2011. - Ч. 1. C. $322-325$.

17. Грунской Т.В., Перхуткин В.П. Сравнительная оценка эффективности методов проходческих работ в нефтешахте Ярегского месторождения // Сб. науч. тр.: материалы науч.-техн. конф., 16-19 апреля 2013 г.: в 3 ч. - Ухта: Ухтинский гос. техн. ун-т, 2013. - Ч. 1. C. $320-323$.

18. Нор Е.В. Прогнозная оценка пылегазового режима воздуха рабочих зон нефтяных шахт при паратепловом воздействии на пласт (на примере Ярегского месторождения высоковязкой нефти): дис. ... канд. техн. наук. - Ухта, 2004. - 130 с.

19. Новиков С.М. Оценка риска для здоровья. Алгоритм расчета доз при оценке риска, обусловленного многосредовыми воздействиями химических веществ. - М., 1999. - 51 с.

20. Новиков С.М., Авалиани С.Л., Буштуева К.А. Оценка риска для здоровья. Опыт применения методологии оценки риска в России. - М., 1999. - 290 с.

21. Анализ и управление риском: теория и практика / Страховая группа «ЛУКОЙЛ». - М., 2016. - 186 с.

22. Методология оценки профессионального риска в медицине труда / Н.Ф. Измеров, Э.И. Денисов, Н.Н. Молодкина [и др.] // Медицина труда и промышленная экология. - 2001. - № 12. - С. 1-7.

23. Хасанова А.А., Шур П.З., Шляпников Д.М. Оценка изменений функций организма под влиянием условий профессиональной деятельности // Вестник Пермского университета. - 2014. - Вып. 2. C. $48-51$.

24. Анализ современных методов и средств мониторинга при подземной разработке полезных ископаемых / Л.А. Гладкова, Б.Ю. Зуев, Р.С. Истомин, М.А. Логинов // Горный информационноаналитический бюллетень. - 2010. - № 4. - С. 19-24. 
25. Хенли Д., Кумамото Х. Надежность технических систем и оценка риска: пер. с англ. М.: Машиностроение, 1984. - 528 с.

26. Елохин А.Н. Анализ и управление риском: теория и практика / Страховая группа «ЛУКОЙЛ». M., 2010. - $186 \mathrm{c}$.

27. Малышев Д.В. Анализ систем управления промышленной безопасностью, охраной труда в РФ и зарубежных нефтегазовых компаниях // Актуальные проблемы состояния и развития нефтегазового комплекса России: тез. докл. 5-й науч.техн. конф. - М.: РГУ нефти и газа им. И.М. Губкина, 2003. - c. 6 .

28. Горская Т.В. Оценка условий труда в металлургии с учетом сочетанного воздействия вредных производственных факторов: дис. ... канд. тех. наук. - М., 2007. - 148 с.

29. Долятовский В.А., Долятовская В.Н. Исследование систем управления. - М.: Март, 2003. - 256 с.

30. Мукминов Р.А., Галлямов М.А. Математическое моделирование процессов охраны труда: учеб. пособие. Уфа: Уфим. нефт. ин-т, 1990. - 74 с.
31. Сербиновский Б Ю., Рудик Е.В. Мониторинг производительности труда. - Новочеркасск: ЛИК, 2010. -260 c.

32. Янг С. Системное управление организацией / пер. с англ. под ред. С.П. Никонорова, С.А. Батасова. М.: Сов. радио, 1972. -456 с.

33. Practical tools and checklists for risk assessment. Приложение 1. Инструмент оценки рисков / Европейское Агентство по обеспечению здоровья и безопасности работников. - Бильбао, 2007.

34. Principles for the assessment of risks to human health from exposure to chemicals. Environmental Health Criteria 210 [Электронный ресурс]. - Geneva: WHO, 1999. URL: http://www.inchem.org/documents/ehc/ehc/ehc210.htm (дата обращения: 12.06.2018).

35. Shimizu Y., Kato H., Schull W.J. Studies of the mortality of a-bomb survivors: 9. Mortality, 1950-1985: Part 2. Cancer mortality based on the recently revised doses (DS86). vol. 121, № 2. - P. 120-141. DOI: 10.2307/3577495

36. Sources, effects and risk of ionizing radiation: Report / United National Scientific Committee on the Effects of Atomic Radiation (UNSCEAR). - Vein, 2000.

Please cite this article in English as:

Grunskoy T.V., Berdnik A.G., Berdnik M.M. The hygienic risk assessment of the development of occupational diseases among personnel that work in thermal mining oil recovery. Perm Journal of Petroleum and Mining Engineering, 2018, vol.18, no.1, pp.85-100. DOI: 10.15593/2224-9923/2018.3.8

Просьба ссылаться на эту статью в русскоязычных источниках следующим образом:

Грунской Т.В., Бердник А.Г., Бердник М.М. Гигиеническая оценка риска развития профзаболеваний у работников, занятых термошахтной добычей нефти // Вестник Пермского национального исследовательского политехнического университета. Геология. Нефтегазовое и горное дело. - 2018. - Т.18, №1. - C.85-100. DOI: 10.15593/2224-9923/2018.3.8 